\title{
New Cretaceous lungfishes (Dipnoi, Ceratodontidae) from western North America
}

\author{
Joseph A. Frederickson, ${ }^{1,2}$ and Richard L. Cifelli ${ }^{1,2}$ \\ ${ }^{1}$ Sam Noble Oklahoma Museum of Natural History, 2401 Chautauqua Avenue, Norman, Oklahoma 73072, USA 〈joseph.a.frederickson-1 @ ou.edu〉 \\ 〈RLC@ou.edu \\ ${ }^{2}$ Department of Biology, University of Oklahoma, 730 Van Vleet Oval, Norman, Oklahoma 73019, USA 〈joseph.a.frederickson-1@ou.edu〉 \\ $\langle$ RLC@ou.edu $\rangle$
}

\begin{abstract}
Ceratodontid lungfishes are generally rare, poorly represented elements of North America's Mesozoic ecosystems, with previously known maximum diversity in the Late Jurassic. Herein we describe four new species of the form genus Ceratodus, from the Cretaceous of the Western Interior, considerably expanding fossil representation of post-Triassic dipnoans in North America. To model taxonomic and morphologic diversity, we adopt a four-fold system of phenetically based species groups, named for exemplars from the Morrison Formation. Ceratodus kirklandi n. sp. (Potamoceratodus guentheri group) and C. kempae n. sp. (C. frazieri group) represent a hitherto unsampled time interval, the Valanginian. Ceratodus nirumbee n. sp. and $C$. molossus n. sp. extend the temporal ranges of the $C$. fossanovum and $C$. robustus groups upward to the Albian and Cenomanian, respectively. These new occurrences show that ceratodontids maintained their highest diversity from the Late Jurassic through the mid-Cretaceous (Albian-Cenomanian), an interval of 60 Myr. The existing record suggests that some of the later (mid-Cretaceous) ceratodontids may have been tolerant of salt water; to date, there is no evidence that they aestivated. Only a few occurrences are known from horizons younger than Cenomanian. Demise of ceratodontids appears to be part of a broader pattern of turnover that occurred at the Cenomanian-Turonian boundary in North America.
\end{abstract}

\section{Introduction}

Though now restricted to southern landmasses, lungfishes were present in North America for much of the Paleozoic and Mesozoic, dating back to the Devonian Period. Early representatives display broad diversity in skull and dental morphology, suggesting differences in trophic adaptations and representation of multiple clades (e.g., Long, 2010; Pardo et al., 2010). Post-Triassic dipnoans of North America, however, are represented almost entirely by small samples (or unique occurrences) of isolated tooth plates-a fossil record that is poorly suited to detailed phylogenetic or paleobiologic understanding, and that is therefore permissive of contrasting perspectives. For example, Martin (1982) proposed family-level distinction of the two major morphs (flat and sharp-crested, referred to Ceratodontidae and Ptychoceratodontidae, respectively) seen among North American Jurassic-Cretaceous varieties. Alternate hypotheses of relationships have been suggested, however (e.g., Kirkland, 1987, 1998), and in view of the fact that the tooth plates are broadly similar in gross anatomical and histological features, they are generally referred to Ceratodus (Agassiz, 1838; see diagnosis in Kemp, 1993), which has long been regarded as a form genus (Schultze, 1981; Kirkland, 1987). That this fossil record imperfectly reflects taxonomic diversity is illustrated by cranial remains recently described for one species (named Ceratodus guentheri by Marsh, 1878; and compared favorably to Ptychoceratodus by Martin, 1982 and some subsequent workers) from the Morrison Formation, which is distinctive enough to warrant placement in a separate genus, Potamoceratodus (Pardo et al., 2010). On the other hand, tooth plates of the closest living species, Neoceratodus forsteri, are sufficiently variable (particularly according to growth stage) that fossils dating as far back as the Early Cretaceous are attributable to it (Kemp and Molnar, 1981; see also Kemp, 1997). The opposing issues of general morphologic conservatism and intraspecific variability pose challenges to interpreting a fossil record that consists mainly of rare, widely scattered occurrences of isolated tooth plates.

Yet the record of North American Jurassic-Cretaceous lungfish is informative in spite of its imperfection. Recognizable species-level distinctions can often be made between isolated specimens or small samples of Ceratodus tooth plates (see Kemp, 1993 and references therein; Kirkland, 1987, 1998). Moreover, the contrasting morphology between the major types of tooth plates (flat versus high-crested) suggests diversity in dietary preference. Species of Ceratodus (and Potamoceratodus) are inferred to have been faunivorous to omnivorous; low-crowned, flat tooth plates are interpreted to reflect adaptation for durophagy, suggesting more reliance on mollusks and, perhaps, vertebrates (Kirkland, 1987; Bakker, 2009; Shimada and Kirkland, 2011). It is also noteworthy that some of the flat-crowned (and presumably durophagous) taxa were the largest fishes of their respective communities; one unnamed species attained an estimated length 
of $4 \mathrm{~m}$ (Shimada and Kirkland, 2011). Smaller species with high-crested tooth plates-suggestive of shearing functionmay have relied more heavily on fare having negligible mineralized tissue, such as soft-bodied invertebrates (Parris et al., 2007). Dietary preference also presumably varied ontogenetically, as in the living Australian lungfish (Neoceratodus forsteri), whose dentition progresses from sharp cones, suitable mainly for apprehending food items, to well-worn crushing plates, which are capable of processing mollusks and other hard-bodied prey (Kemp, 1986).

Lungfishes were geographically and stratigraphically widespread in the Cretaceous of North America, and include fossils ranging from the Albian of Montana and Wyoming (Ostrom, 1970; Oreska et al., 2013) to the Late Cretaceous (probably Campanian) of New Jersey (Parris et al., 2004). Occurrences within this broad temporal and geographic range are sparse and rare, however. All but two are from western North America (Parris et al., 2004; Frederickson et al., 2016), and overall taxonomic representation is meager. Herein we report new dipnoan fossils from Cretaceous units spanning the Valanginian-Cenomanian of North America's Western Interior Basin (see Kauffman and Caldwell, 1993). These include representation of four new species named herein: Ceratodus kempae n. sp., C. kirklandi n. sp., C. molossus n. sp., and C. nirumbee n. sp. We also add to knowledge of Jurassic C. stewarti Milner and Kirkland, 2006 by referring an upper tooth plate to the species. These new fossils, together with critical appraisal of other occurrences, provide basis for evaluating ceratodontid diversity (morphologic and taxonomic) through the Cretaceous of North America.

\section{Materials and methods}

Standardized angles and reference points (Kirkland, 1987 and references therein; abbreviations for structures used as basis for measuring angles are illustrated in Fig. 1) were measured from photographs of specimens described herein (Table 1). We present these data mainly to provide consistent frame of reference with respect to previous studies on North American ceratodontids (e.g., Kirkland, 1987, 1998; Parris et al., 2004, 2014; Main, 2013; Main et al., 2014). Phylogenetic utility of these measurements is limited, largely owing to a lack of basis for assessing variability: most North American taxa are known by one or a few specimens. Further, in Australian lungfishes, angles of the ridge crests can be very similar, even in visually distinct tooth plates (Kemp and Molnar, 1981; Kemp, 1997). In this study, we compared gross morphology using the published descriptions and anatomical terminology of Kirkland (1987). Since there is currently no single set of characters that can be used to accurately diagnose all fossil lungfish species, qualitative approaches that follow the outlines suggested by Kirkland (1987) and Kemp (1997) are used to define the taxonomic boundaries between species. Finally, no attempt is made to reconstruct phylogenetic relationships, because most of these specimens are composed solely of tooth plates having limited morphological information.

Except where indicated otherwise, specimens reported herein were collected from Federal lands administered by the

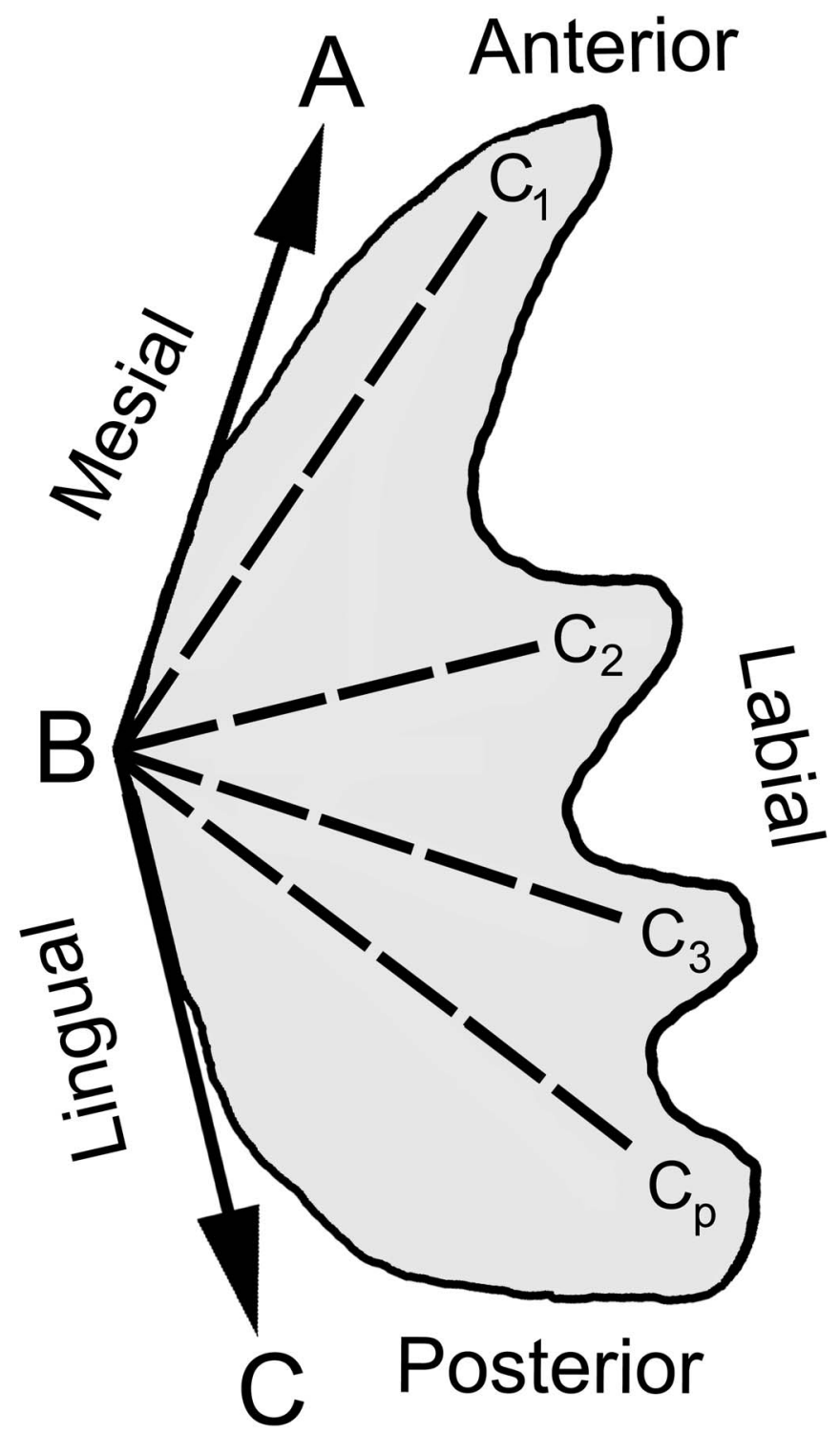

Figure 1. A hypothetical Ceratodus right prearticular plate showing orientation, basis for angles, and abbreviations for crests, following Kirkland (1987, 1998).

U.S. Bureau of Land Management, which maintains and restricts access to specific locality coordinates. For southern and central Utah, the rock unit traditionally cited as the Dakota Formation is herein termed the Naturita Formation (see Young, 1960; Carpenter, 2014).

Repositories and institutional abbreviations.-Specimens mentioned in this study are deposited in the following institutions: AMNH, American Museum of Natural History, New York, New York, U.S.A.; BYU, Paleontological Collections, Brigham Young University, Provo, Utah, U.S.A.; DMNS, Denver Museum of Nature and Science, Denver, Colorado, U.S. A.; KUVP, Vertebrate Paleontology Collection, University of Kansas Natural History Museum, Lawrence, Kansas, U.S.A.; MCZ, Museum of Comparative Anatomy, Harvard University, Cambridge, Massachusetts; MNA, Museum of Northern Arizona, Flagstaff, Arizona, U.S.A.; MOR, Museum of the 
Table 1. Measurements of Ceratodus tooth plates described in this work. Angles, in degrees, were measured following protocol outlined and illustrated by Kirkland (1987, fig. 1; see Fig. 1 herein). $\mathrm{ABC}=$ angle between mesial (line $\mathrm{A}-\mathrm{B}$ ) and lingual (line $\mathrm{B}-\mathrm{C})$ borders, $\mathrm{C}_{1} \mathrm{C}_{\mathrm{p}}=\mathrm{angle}$ between lines defined by first $\left(C_{1}\right)$ and last $\left(C_{p}\right)$ crests, $C_{2} C_{p}=$ angle between lines formed by second $\left(C_{2}\right)$ and last $\left(C_{p}\right)$ crests, $C_{3} C_{p}=$ angle between lines formed by third $\left(C_{3}\right)$ and last $\left(C_{p}\right)$ crests, Max. $\mathrm{L}=$ maximum length is the end of $\mathrm{C}_{1}$ to $\mathrm{C}_{\mathrm{p}}$ from the labial margin in $\mathrm{mm}$, Max. $\mathrm{W}=$ maximum width is the labial margin to the lingual-mesial margin junction in $\mathrm{mm}$.

\begin{tabular}{|c|c|c|c|c|c|c|c|c|}
\hline Species & Specimen & Plate & $\mathrm{ABC}$ & $\mathrm{C}_{1} \mathrm{C}_{\mathrm{p}}$ & $\mathrm{C}_{2} \mathrm{C}_{\mathrm{p}}$ & $\mathrm{C}_{3} \mathrm{C}_{\mathrm{p}}$ & Max. L & Max. W \\
\hline$\overline{C \text {. stewarti }}$ & OMNH 69332 & Upper & 130 & 86 & 55 & 29 & 9.8 & 4.9 \\
\hline \multirow[t]{3}{*}{ C. molossus } & NCSM 30253 & Upper & 135 & 69 & 49 & 20 & 62.8 & 36.9 \\
\hline & UMNH 16774 & Upper & 136 & 70 & 44 & 19 & - & 35.2 \\
\hline & MNA.V.10649 & Lower & 149 & 76 & 47 & 20 & 39.1 & 23.8 \\
\hline \multirow[t]{7}{*}{ C. kirklandi } & BYU 20808 & Upper & 118 & 82 & 52 & 25 & 26.2 & 14.1 \\
\hline & BYU 20810 & Lower & 121 & 86 & 56 & 28 & 26.8 & 14.1 \\
\hline & BYU 20811 & Upper & 121 & 85 & 56 & 28 & 25.3 & 14.3 \\
\hline & BYU 20807 & Lower & 124 & 92 & 46 & 16 & 30 & - \\
\hline & BYU 20809 & Lower & 121 & 88 & 54 & 22 & 25.7 & 11.1 \\
\hline & BYU 20812 & Lower & 133 & - & 52 & 26 & - & 10.4 \\
\hline & BYU 20813 & Lower & 141 & 92 & 59 & 26 & 28.3 & 13.3 \\
\hline C. nirumbee & OMNH 34765 & Lower & 121 & 88 & 54 & 22 & 29.5 & 14.5 \\
\hline C. kempae & BYU 20814 & Upper & 111 & - & 45 & 21 & - & 20.3 \\
\hline
\end{tabular}

Rockies, Bozeman, Montana; NCSM, North Carolina Museum of Natural Sciences, Raleigh, North Carolina, U.S.A.; NJSM, New Jersey State Museum, Trenton, New Jersey, U.S.A.; OMNH, Sam Noble Oklahoma Museum of Natural History, Norman, Oklahoma, U.S.A.; SDSM, Museum of Geology, South Dakota School of Mines and Technology, Rapid City, South Dakota, U.S.A.; TATE, Tate Museum, Casper, Wyoming, U.S.A.; UCM, University of Colorado Museum, Boulder, Colorado, U.S.A.; UMNH-VP, Vertebrate Paleontology Collection, Utah Museum of Natural History, Salt Lake City, Utah, U.S.A.; UNSM, University of Nebraska State Museum, Lincoln, Nebraska, U.S.A.; USNM, National Museum of Natural History (formerly United States National Museum), Smithsonian Institution, Washington, D.C., U.S.A.; UTA-AAS, University of Texas at Arlington, Arlington Archosaur Site, Arlington, Texas, U.S.A. (numbers cited from Main et al., 2014, specimens are now deposited at the Perot Museum of Science and Nature, Dallas, Texas, U.S.A.); UWM, University of Wyoming Museum, Laramie, Wyoming, U.S.A.; VOF, Valley of Fire State Park, currently curated at the Nevada State Museum and Historical Society, Las Vegas, Nevada, U.S.A; YPM, Yale Peabody Museum, New Haven, Connecticut, U.S.A.

\section{Systematic paleontology}

Subclass Dipnoi Müller, 1846

Order Ceratodontiformes Berg, 1940

Family Ceratodontidae Gill, 1872

Genus Ceratodus Agassiz, 1838

Type species.—Ceratodus latissimus Agassiz, 1838.

\section{Ceratodus stewarti Milner and Kirkland, 2006}

Figure 2.1, Table 1

2006 Ceratodus stewarti Milner and Kirkland, p. 515, fig. 7B.

Holotype.-Prearticular plate with fused prearticular (UMNH-VP 16037), Early Jurassic, from the Whitmore Point Member, Moenave Formation; $12 \mathrm{~km}$ east of St. George, Washington County, Utah, U.S.A. (Milner and Kirkland, 2006, fig. 1B).

Emended diagnosis.-Lower tooth plates with four primary ridges (the fourth ridge being twinned); upper tooth plate has five ridges with the fifth being twinned; both upper and lower tooth plates have relatively tall ridges, with $\mathrm{C}_{1} \mathrm{C}_{\mathrm{p}}$ angle being slightly acute.

Occurrence.-Lower Jurassic (Hettangian-Sinemurian), southern Utah. The newly referred specimen (OMNH 69332) is from OMNH locality V1737, 4 km west of Goblin Valley State Park, Emery County, Utah, U.S.A.; Kayenta Formation (Lower Jurassic, Sinemurian, see Lucas et al., 2005).

Description.-Milner and Kirkland (2006) described C. stewarti based on a single prearticular tooth plate. The prearticular plate of this species is distinct in its possession of a twinned fourth ridge (here defined as a single crest arising from central mound that splits into two crests before reaching the labial margin), such that five functional cutting surfaces are present; a trait not known to occur in any other ceratodontid from the Jurassic. This species is most similar to Potamoceratodus guentheri

Figure 2. Ceratodus from North America. (1) C. stewarti, OMNH 69332, left pterygopalatine plate in occlusal view; OMNH locality V1737, Emery County, Utah, Kayenta Formation, Lower Jurassic (Sinemurian). (2-7) C. molossus n. sp. (2, 3) Occlusal and dorsal views, respectively, of NCSM 30253 (holotype), right pterygopalatine plate; locality near Emery, Emery County, Utah, Mussentuchit Member, Cedar Mountain Formation, Upper Cretaceous (Cenomanian). $(4,5)$ Occlusal and dorsal views, respectively, of UMNH 16774, right pterygopalatine plate; locality near Escalante, Garfield County, Utah, Naturita Formation, Upper Cretaceous (Cenomanian). (6, 7) Occlusal and inferior views, respectively, of MNA.V.10649, right prearticular plate; MNA locality 1067, Garfield County, Utah, Naturita Formation, Upper Cretaceous (Cenomanian). (8, 9) C. nirumbee n. sp., occlusal and inferior views, respectively, of OMNH 34765 (holotype), right prearticular plate; OMNH locality V1061, Carbon County, Montana, Cloverly Formation, Lower Cretaceous (Albian). (10, 11) C. kempae n. sp., BYU 20814 (holotype), right pterygopalatine plate in occlusal and dorsal views, respectively; pter. = pterygoid; BYU locality 1783, Grand County, Utah; Yellow Cat Member, Cedar Mountain Formation, Lower Cretaceous (Valanginian). (12, 13) C. frazieri, OMNH 60408, right prearticular plate in occlusal and inferior views; OMNH locality 1075, Big Horn County, Montana; Cloverly Formation, Lower Cretaceous (Albian). (14, 15) C. gustasoni, OMNH 66043, left prearticular plate in occlusal and inferior views, respectively; OMNH locality V808, Garfield County, Utah; Naturita Formation, Upper Cretaceous (Cenomanian). 


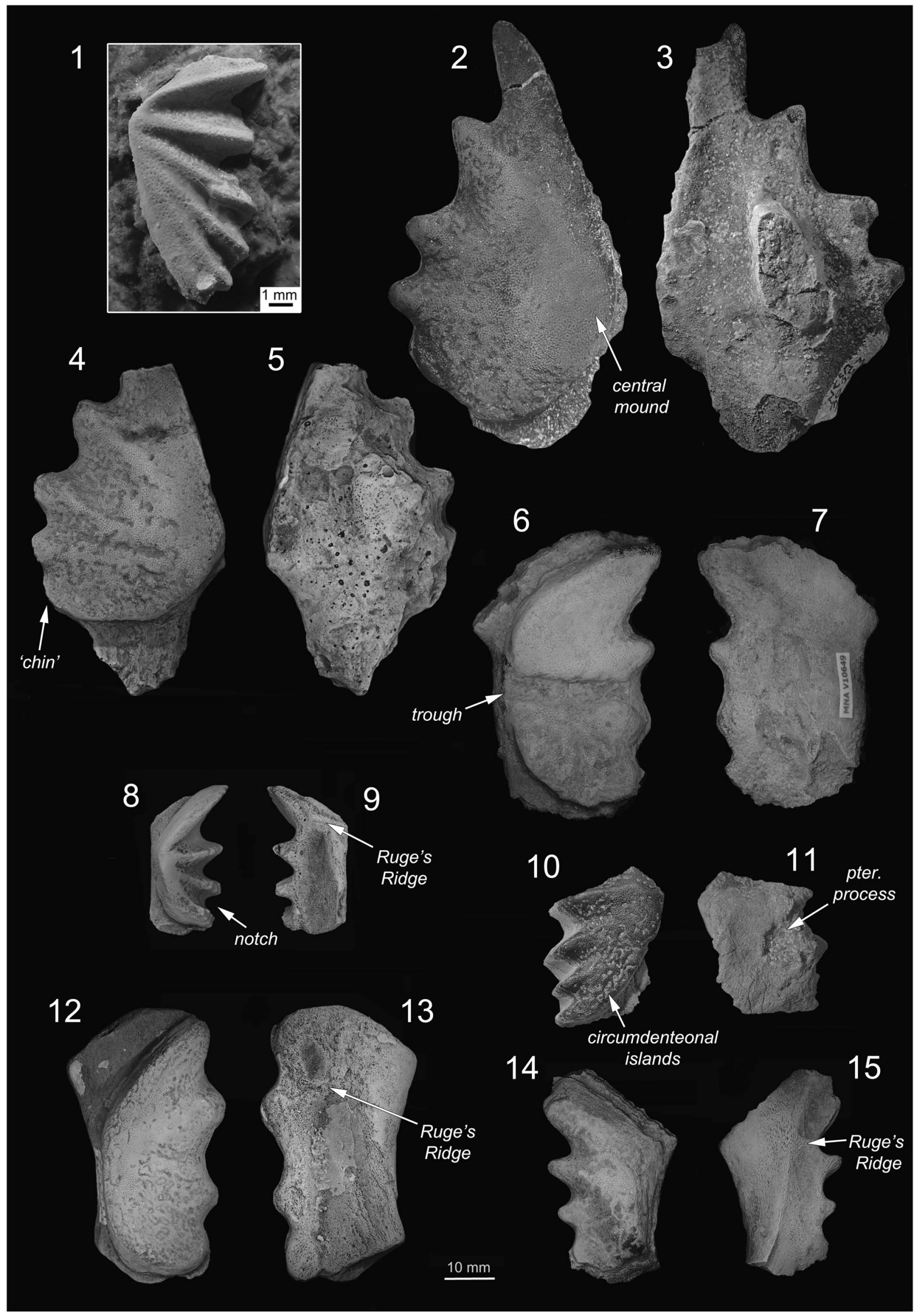


in the possession of tall ridges, with an acute $\mathrm{C}_{1} \mathrm{C}_{\mathrm{p}}$ angle. The upper (pterygopalatine) plate attributed to the species here (Fig. 2.1) similarly has a twinned fifth ridge crest, giving this specimen six functional cutting surfaces. The upper plate, like the lower, has a slightly acute $\mathrm{C}_{1} \mathrm{C}_{\mathrm{p}}$ angle and well-defined crests or ridges.

Materials.-UMNH-VP 16037 (holotype), prearticular plate with fused prearticular; and OMNH 69332, left pterygopalatine tooth plate.

Remarks.-We have emended the diagnosis of C. stewarti in order to account for the referred pterygopalatine plate, the morphology of which was anticipated by Milner and Kirkland (2006). The referred specimen extends the geologic range of C. stewarti upward to the Sinemurian. Milner and Kirkland (2006) also mentioned a prearticular tooth plate, MCZ 13865, from the Kayenta Formation of nearby northern Arizona (see Lucas et al., 2005), referring it to Ceratodus cf. C. guentheri. We agree with this assignment (see discussion).

Ceratodus kirklandi new species

Figure 3.1-3.9, Supplemental Data 1, 2, Table 1

Holotype.-BYU 20808, right pterygopalatine plate with attached pterygopalatine, Early Cretaceous (Valanginian, based on Hendrix et al., 2015), lowest part of Yellow Cat Member, Cedar Mountain Formation; BYU locality 1667, $14 \mathrm{~km}$ southwest of Cisco, Grand County, Utah, U.S.A.

Diagnosis. - A ceratodontid of moderate size; pterygopalatine plate with five ridges and a fifth ridge crest that is variably expanded into a flat crushing surface, with twinning present. Prearticular plate with four main ridges; fourth ridge always twinned, giving the specimens five ridge crests. Prearticular plates have a groove on the lingual edge of the occlusal surface to accommodate the inner angle of the upper tooth plate.

Occurrence.-Known only from the type locality, Grand County, Utah; Yellow Cat Member of the Cedar Mountain Formation (Lower Cretaceous).

Description.-The available sample of this species includes two pterygopalatine and five prearticular tooth plates, all with platebearing element attached. Pterygopalatine plates are similar in size and complete prearticular plates vary only slightly in maximum length (Table 1). All plates are sharply crested and angles between crests are relatively acute (see $C_{1} C_{p}$ values, Table 1). The occlusal surfaces on the margins of both the upper and lower plates show wear from the opposing tooth plates. In both plates the wear is angled, sharpening the ridges and crests with increased use. Wear on the lower plates is more heavily developed on the mesial side of the ridge crests, while on the upper plates it is heavier on the lingual side of the ridge crests. In general it appears that the pterygopalatine plates are more deeply incised than the prearticular plates.

The pterygopalatine plates have five main crests, each bearing up to eight denticles ( $C_{2}$ of BYU 20808). Crest five of BYU 20808 broadens into a flat surface distally and a faint sixth crest is present at the posterior margin (Fig. 3.1). The pterygopalatine (the bone to which the plate is fused) is undiagnostic, except for the pterygoid process, which is relatively small and pointed by comparison to other ceratodontids we have studied. Prearticular tooth plates also bear denticles on the crests, but they are less distinct and numerous (e.g., two are present on $\mathrm{C}_{2}$ of BYU 20813, Fig. 3.4) than on pterygopalatine plates. Four major crests are present, but the last is invariably twinned into two well-defined crests, giving a total of five. On the inferior side of the prearticular (Fig. 3.5), Ruge's Ridge is developed underneath and medial to the $C_{1}-C_{2}$ ridges, as is commonly seen among North American ceratodontids.

Etymology.-Named in honor of Dr. James Ian Kirkland, in recognition of his substantial contributions to the study of Mesozoic lungfishes and to knowledge of the Cedar Mountain Formation and its contained fossils.

Materials.-Seven tooth plates, including the holotype, as follows: BYU 20807, an incomplete right prearticular plate with partial prearticular; BYU 20808 (holotype), a complete right pterygopalatine plate with preserved pterygopalatine; BYU 20809, complete left prearticular plate with partial prearticular; BYU 20810, a complete right pterygopalatine plate with partial pterygopalatine; BYU 20811, a complete left pterygopalatine plate with partial pterygopalatine; BYU 20812, an incomplete left prearticular plate, probably from an immature individual; and BYU 20813, a complete left prearticular plate with complete prearticular.

Remarks.-Ceratodus kirklandi is only the second North American, Early Cretaceous ceratodontid that is represented by multiple upper and lower plates from the same site. These specimens are probably the basis for listing of "Ceratodus undescribed new species" in the Yellow Cat Member, Cedar Mountain Formation, by Kirkland et al. (1999, p. 206). Like C. stewarti and Potamoceratodus guentheri, C. kirklandi possesses tall ridges with crest angles $\left(\mathrm{C}_{1} \mathrm{C}_{\mathrm{p}}\right)$ being slightly acute. Ceratodus kirklandi is most similar to $C$. stewarti from the Moenave and Kayenta formations. Both species have prearticular tooth plates with a twinned fourth ridge crest, a condition unknown in any other North American species of Ceratodus (Milner and Kirkland, 2006). Similarly, the pterygopalatine fifth ridge is twinned in C. stewarti (based on the newly referred specimen, OMNH 69332) and variably twinned, at least, in C. kirklandi. Kemp (1997) argued against the use of

Figure 3. Ceratodus kirklandi n. sp. All specimens are from BYU locality 1667, Grand County, Utah; Yellow Cat Member, Cedar Mountain Formation, Lower Cretaceous (Valanginian). (1, 2) BYU 20808 (holotype), right pterygopalatine plate in occlusal and dorsal views, respectively; pter. = pterygoid. (3) BYU 20811, left pterygopalatine plate in occlusal view. (4, 5) BYU 20809, left prearticular plate in occlusal and inferior views, respectively. (6) BYU 20807, right prearticular plate in occlusal view. (7) BYU 20812, left prearticular plate in occlusal view. (8) BYU 20813, left prearticular plate in occlusal view. (9) BYU 20810, left prearticular plate in occlusal view. 


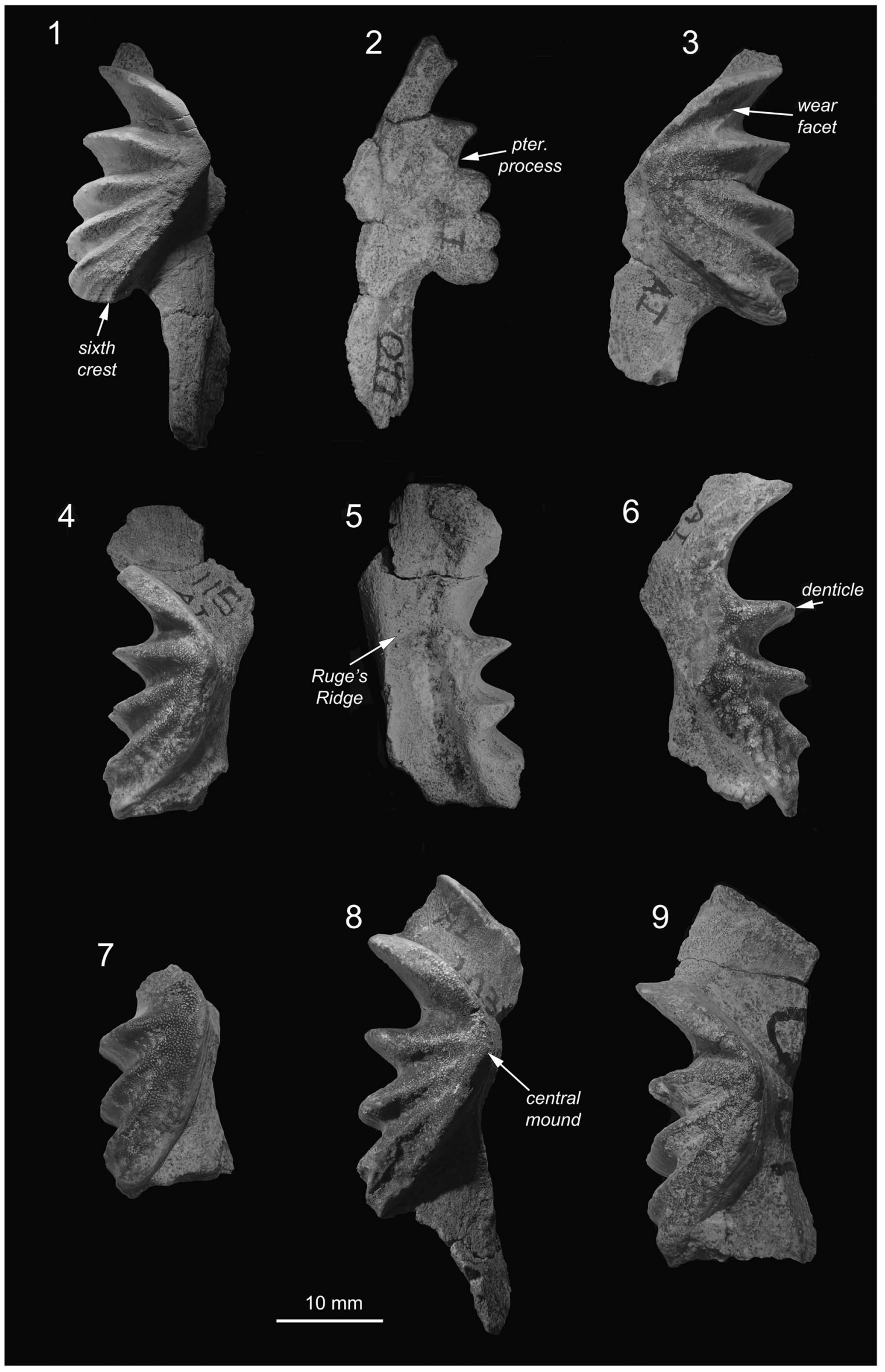


these divided ridges as taxonomic characters, based on observations of variable twinning of the last ridge crest in the living Australian lungfish (Neoceratodus forsteri). Our survey of postTriassic ceratodontids of North America suggests that this condition is often absent, or at least extremely rare, in most species. Here, we follow Milner and Kirkland (2006) and attribute taxonomic significance to this feature.

\section{Ceratodus molossus new species}

Figure 2.2-2.7, Supplemental Data 3-5, Table 1

Holotype.-NCSM 30252, a robust, complete right pterygopalatine plate with a partial pterygopalatine attached; Late Cretaceous, Mussentuchit Member, Cedar Mountain Formation; $31 \mathrm{~km}$ south of Emery, Emery County, Utah, U.S.A.

Diagnosis. - A ceratodontid bearing four primary ridge crests on the pterygopalatine plate, with the last being twinned slightly into an exposed 'chin' on the posterolabial corner; mesial margin strongly linear. Both pterygopalatine and prearticular plates have a highly obtuse inner angle ( $\mathrm{ABC}$ exceeding $130^{\circ}$ ) in combination with a strongly acute $\mathrm{C}_{1} \mathrm{C}_{\mathrm{p}}$ angle $\left(69-76^{\circ}\right)$ and nearly planar occlusal surfaces, with negligible development of crests. The prearticular plate is characterized by rounded lingual and posterior margins, and a thick but short $\mathrm{C}_{1}$ ridge crest.

Occurrence.-Upper Cretaceous (Cenomanian), Cedar Mountain and Naturita formations, Utah, U.S.A. The referred prearticular specimen (MNA.V.10649) is from MNA locality 1067, $2.4 \mathrm{~km}$ northwest of Cannonville, Garfield County, Utah, U.S. A. The referred pterygopalatine plate (UMNH 16774) is also from the Naturita Formation, near Escalante, Garfield County, Utah, U.S.A.

Description.-The holotype specimen (NCSM 30252) is a large, right pterygopalatine plate with a complete occlusal surface. An additional specimen, very similar to the holotype, is also described here. UMNH 16774 is a large, right pterygopalatine plate, complete except for the tip of $\mathrm{C}_{1}$. Both known pterygopalatine plates (Fig. 2.2-2.5) strongly resemble the pterygopalatine plate of Ceratodus robustus (Knight, 1898, fig. 1), particularly in its large size, extreme flattening of the occlusal surface, shallow and rounded notches between ridges (greatest separation is between $\mathrm{C}_{1}-\mathrm{C}_{2}$ ), and squared posterior margin (Kirkland, 1987, pl. 1N; 1998, fig. 3I). These plates differs from C. robustus in having a twinned $\mathrm{C}_{\mathrm{p}}$ ridge crest; also, ridge crests are thinner, with $\mathrm{C}_{3}$ and $\mathrm{C}_{\mathrm{p}}$ ridge crests slightly more distinct (the latter noticeably shorter than in $C$. robustus). In addition, the elongate, finger-like $\mathrm{C}_{1}$ ridge crest of the holotype specimen is not observed in $C$. robustus. The large projection seen on the mesiolingual border (junction of inner angle) of $C$. robustus is also present in NCSM 30252 and UMNH 16774, but is broader and does not project as far lingually.

The prearticular plate referred to Ceratodus molossus (MNA.V.10649, Fig. 2.6, 2.7) is complete; one complete and several partial prearticular plates of $C$. robustus are available for comparison (Kirkland, 1987, plate 1P-T; 1998, fig. 3H, J). MNA.V.10649 is slightly smaller than would be expected for the individual represented by the holotype, NCSM 30252, but it is morphologically appropriate and would occlude well with the holotype, were it not for minor deformation of the prearticular tooth plate surface (see below). As with the upper plates, the prearticular tooth plate of $C$. molossus is similar to that of C. robustus, particularly in its massive construction, negligible expression of ridge crests on the occlusal surface, and the shallowness of the notches between ridges. MNA.V.10649 bears four ridges, of which $\mathrm{C}_{1}$ and $\mathrm{C}_{2}$ are widely spaced; the distance between $\mathrm{C}_{2}-\mathrm{C}_{3}$ is slightly greater than between $\mathrm{C}_{3}-\mathrm{C}_{\mathrm{p}}$, whereas $\mathrm{C}_{2}-\mathrm{C}_{4}$ tend to be more closely spaced, with more angulate intervening notches, in $C$. robustus. In both, the mesial margin differs from other North American species of Ceratodus in being rounded. In C. molossus, this rounded mesial margin is continuous with similarly curved lingual and posterior margins, giving the plate a semilunate shape. The lingual and posterior margins are straighter in C. robustus. TATE 3000 (Kirkland, 1998, fig. 3J), the only complete prearticular plate known for C. robustus, is proportionately more labiolingually expanded (especially on the mesial end, where $C_{1}$ is particularly broad) than MNA.V.10649, but other specimens of $C$. robustus suggest variability in proportions of the prearticular plate.

Intriguingly, the occlusal surface of MNA.V.10649 is somewhat bowed, with the central portion being concave; a distinct trough ( $4 \mathrm{~mm}$ wide and $2-3 \mathrm{~mm}$ deep) runs labiolingually across the center. These are readily identified as pathologies, of which a number are known for fossil and living lungfishes; the condition in MNA.V.10649 is closely matched in a specimen of Triassic Ceratodus kaupi (Kemp, 2001, fig. 6B; see also Kemp, 2003).

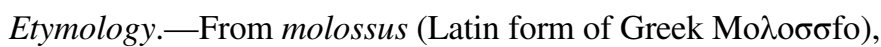
after the extinct breed of Greco-Roman fighting dog (De Prisco and Johnson, 1990), named in reference to Bulldog Bench near Cannonville, Utah, U.S.A., where the prearticular specimen (and other lungfish material) was found. The name is also an allusion to the presumed large and powerful feeding apparatus of the species, reminiscent of that of a bulldog or mastiff.

Materials.-Three nearly complete tooth plates, including the holotype: NCSM 30252 (holotype), a right pterygopalatine plate; UMNH 16774, a right pterygopalatine plate; and MNA. V.10649, a right prearticular plate.

Remarks.-With the addition of C. molossus, the already diverse ichthyofauna of the Naturita Formation (see Brinkman et al., 2013) now includes two species of Ceratodus. Ceratodus gustasoni Kirkland, 1987, like C. molossus, has flat, low-crested tooth plates; though represented by a number of specimens, only the lower (prearticular) tooth plate is known. It can be readily distinguished from that of $C$. molossus in that it is proportionately narrower labiolingually, with $\mathrm{C}_{1}$ being elongate and narrow, the crushing surface at the origin of ridge crests more mound-like, the lingual margin straight, and the $\mathrm{C}_{2}-\mathrm{C}_{\mathrm{p}}$ ridge crests sharply pointed. Ceratodus molossus provides a striking point of contrast with the other recognized Cenomanian species, C. carteri Main, Parris, Grandstaff, and Carter, 2014, from the Woodbine Formation of Texas, which has small, sharply crested tooth plates. 
Ceratodus nirumbee new species

Figure 2.8, 2.9, Supplemental Data 6, Table 1

Holotype--OMNH 34765, a complete right prearticular plate, Early Cretaceous (Albian, see Cifelli and Davis, 2015), lower unit VII (stratigraphic nomenclature of Ostrom, 1970), Cloverly Formation; OMNH locality V1061, $11 \mathrm{~km}$ east northeast of Edgar, Carbon County, Montana, U.S.A.

Diagnosis.—A tall-crested, medium-sized ceratodontid most closely resembling $C$. fossanovum, differing in the extreme mesial placement of Ruge's Ridge; ridge crests more distinct, particularly near area of common origin, with narrower crest $C_{p}$ and better developed $\mathrm{C}_{3}-\mathrm{C}_{\mathrm{p}}$ notch; and a more angulate, less rounded posterolingual margin.

Occurrence.-Known only from the type locality, Cloverly Formation (Albian, Early Cretaceous), Carbon County, Montana, U.S.A.

Description.-OMNH 34765 is a complete right prearticular tooth plate with fused prearticular; it is slightly water-worn, lacking the anterior and posterior processes of the prearticular, and has well-developed occlusal wear. The plate bears four tall, well-defined ridge crests and a small crushing surface at the origin of crests $\mathrm{C}_{1}-\mathrm{C}_{2}$. Crest $\mathrm{C}_{1}$ bears three denticles in a single row; four denticles in a non-linear arrangement are present on $\mathrm{C}_{2} ; \mathrm{C}_{3}-\mathrm{C}_{4}$ begin with double rows of denticles and have an irregular arrangement. OMNH 34765 represents a mediumsized lungfish, larger than Potamoceratodus guentheri and smaller than Ceratodus gustasoni, most resembling C. fossanovum from the Morrison Formation. OMNH 34765 possesses similar ridge crest angles (Table 1) to C. fossanovum, and falls within the range of variation for this species (see values for C. "guentheri" in Kirkland, 1987). However, OMNH 34765 differs from $C$. fossanovum based on suite of characters not found on any of the published specimens from the Jurassic. Ceratodus fossanovum possesses a well-developed crushing platform on the lingual side of prearticular tooth plates, joining the origins of the ridges for the $\mathrm{C}_{3}$ and $\mathrm{C}_{\mathrm{p}}$ ridge (Kirkland, 1987, plate 1D), which is not developed in OMNH 34675. This platform can be seen in lingual view as a second convexity, more posterior to the tall platform formed from the intersection of the $\mathrm{C}_{1}$ and $\mathrm{C}_{2}$ ridges in $C$. fossanovum. The notch (sulcus) between the $\mathrm{C}_{3}$ and $\mathrm{C}_{\mathrm{p}}$ ridge crests is deeper and better developed in OMNH 34765 than in C. fossanovum. On the inferior surface of the underlying prearticular (Fig. 2.9), OMNH 34765 has a welldeveloped median trough or groove that terminates mesially at Ruge's Ridge, which is more distally placed in other species.

Etymology.-From the Crow, Nirumbee, Little People of the Pryor Mountains; dwarves or devils with a ferocious temperament, sharp teeth, and a predilection for meat (Murray, 2008). Allusion is to the presumed feeding habits of the species and to proximity of the type locality to the Pryor Mountains, specifically what is now Chief Plenty Coups State Park, where the legendary Crow leader drew inspiration from the Nirumbee (Linderman, 1957).
Remarks.-Ceratodus nirumbee cannot be readily confused with the other ceratodontid known from the Cloverly Formation, C. frazieri Ostrom, 1970, which is characterized by large, flat-crowned tooth plates (Fig. 2.12-2.13). Oreska et al. (2013) mentioned two ceratodontids among the specimens they collected via underwater screen washing of rock matrix from the Cloverly Formation: C. frazieri and Ceratodus cf. P. guentheri. The specimens are too fragmentary to be identified with confidence, but USNM 546679 (Oreska et al., 2013, fig. 5B) much resembles OMNH 34765, holotype of C. nirumbee, particularly in the presence of a long, thin $\mathrm{C}_{3}$ ridge crest that is subequal to the $\mathrm{C}_{2}$ ridge crest. We provisionally consider this specimen, at least, as belonging to the species. Similarly, Bonde (2008) and Bonde et al. (2008) briefly described and figured a pterygopalatine tooth plate (VOF-2005-03-2A-001) from the Albianaged Willow Tank Formation of southern Nevada, similar in shape to the holotype of $C$. nirumbee. If this specimen does in fact represent an upper plate for $C$. nirumbee, it vastly increases our knowledge of the morphology for this species. Until more robust comparative studies can be done, we informally attribute this specimen to the species as well.

Ceratodus kempae new species

Figure 2.10, 2.11, Supplemental Data 7, Table 1

Holotype.-BYU 20814, right pterygopalatine tooth plate and attached pterygopalatine, complete except for $\mathrm{C}_{1}$; Early Cretaceous (Valanginian, see Hendrix et al., 2015); BYU locality 1783, $16.7 \mathrm{~km}$ southwest of Cisco, Grand County, Utah, U.S.A.

Diagnosis.-Moderate-sized species of Ceratodus, slightly smaller than C. gustasoni, which it resembles in having little surface relief on tooth plate crowns, lack of denticles on ridge crests, obvious circumdenteonal islands present on occlusal surface, and ridges that narrow and are pointed labially. Differs from C. gustasoni and other flat-plated North American species of Ceratodus in having less obtuse $\mathrm{C}_{1}-\mathrm{C}_{\mathrm{p}}$ angle, slightly betterdeveloped ridge crests, serrated labial plate margin (angulate ridge termini separated by angulate notches), and presence of prominent vertical wear facets between ridges.

Occurrence.-Known only from the type locality, Yellow Cat Member, Cedar Mountain Formation (Valanginian, Lower Cretaceous), Grand County, Utah, U.S.A.

Description.-BYU 20814 is missing $\mathrm{C}_{1}$ of what was originally a five-crested right pterygopalatine tooth plate. The preserved part of the mesial margin indicates angle $\mathrm{ABC}$ to be $111^{\circ}$ (Table 1), less than the flat-crowned C. gustasoni or C. frazieri (Kirkland, 1987, table 1). The specimen is of moderate size, considerably smaller than in C. frazieri and larger than $P$. guentheri or C. kirklandi. The occlusal surface is low and undulating, with a modestly developed central mound, where the ridges originate at the mesiolingual corner of the plate. Ridge crests are faint but are better developed than in the most closely similar taxon, C. gustasoni (Fig. 2.14, 2.15). All of the labial ridge tips are distinctly angular, as are the intervening notches, such that the labial margin of the plate has a serrated 
Table 2. Post-Triassic North American lungfish recognized in this study; $C .=$ Ceratodus; $P .=$ Potamoceratodus .

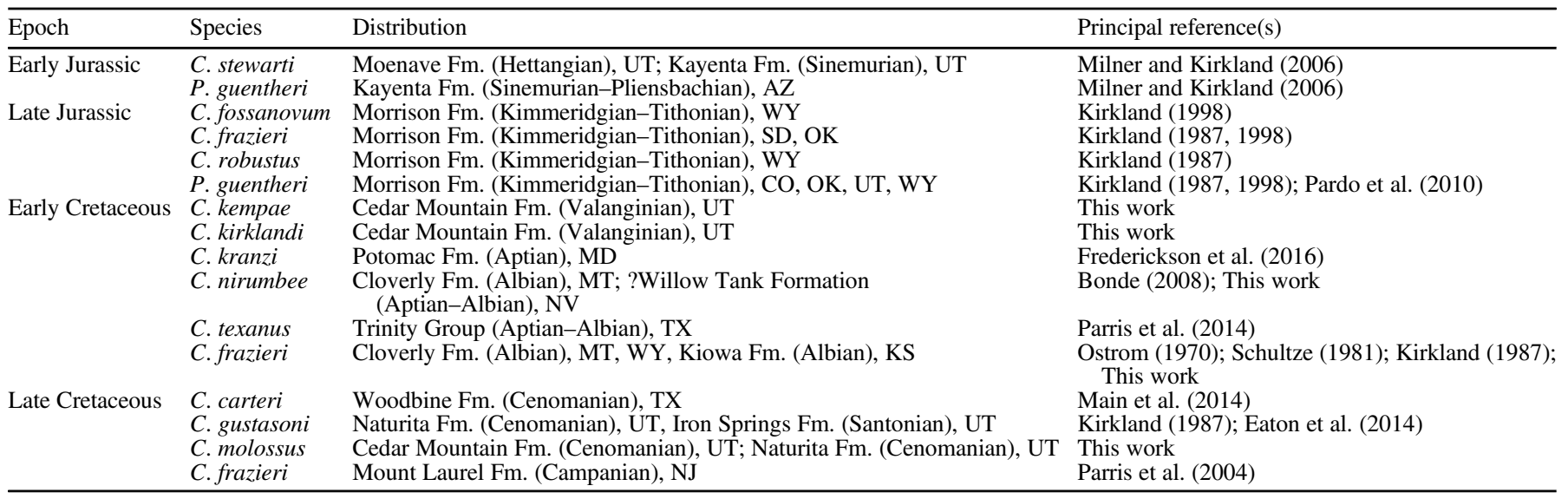

appearance - an appearance enhanced by the fact that the tips lie in a linear configuration (rather than rounded, as is typically the case). Also, the $\mathrm{C}_{\mathrm{p}}$ tip is distinctive in being elongate and slender. The occlusal surface is worn and much resembles that of other flat-crowned plates, such as those of $C$. frazieri or C. gustasoni, in having a cratered appearance owing to the presence of circumdenteonal dentin islands. Wear is also distinct on the near-vertical surfaces in the notches between ridges. The dorsal surface of the fossil reveals the presence of a now-broken but originally large pterygopalatine process above $\mathrm{C}_{2}-\mathrm{C}_{3}$, similar to the condition in OMNH 04033, referred to $C$. frazieri (Kirkland, 1998), and differing from C. kranzi, in which it lies above $\mathrm{C}_{3}-\mathrm{C}_{4}$ (Frederickson et al., 2016).

Etymology.-For Anne Kemp, in recognition of her many contributions to understanding the evolution and biology of lungfishes, past and present.

Remarks.-Ceratodus kempae is clearly a flat-crested lungfish, with tooth plates that presumably emphasized crushing function (Parris et al., 2014): the occlusal aspect of the tooth plate has little topography, ridges lack denticles, and the surface has a pock-marked texture owing to dentin structure. On the other hand, $C$. kempae resembles sharp-crested species such as $P$. guentheri and $C$. kirklandi in its relatively small size, low inner $(\mathrm{ABC})$ angle, presence of ridge crests (though faint), and slender, angulated labial ridge tips that are separated by angular notches. In these respects, $C$. kempae is structurally intermediate between flat-crowned and sharpcrested ("ceratodont" and "ptychoceratodont," Parris et al., 2014 , p. 279) morphologies. This combination of characters is novel in the North American record, prompting us to give it formal taxonomic recognition.

Three other fragments of lungfish tooth plates have thus far been recovered from the surface at BYU locality 1783. These are small, suggesting that they may belong to juvenile individuals, and are too fragmentary for confident identification, but the presence of sharp ridges on each suggests that they may belong to $C$. kirklandi, also known from the Yellow Cat Member of the Cedar Mountain Formation.

\section{Discussion}

North American ceratodontids in space and time.-Given the general scarcity of dipnoan fossils in the Jurassic-Cretaceous of North America, coupled with intraspecific variability and low information content of most specimens (tooth plates), some identifications and taxonomic issues are problematic. Formal systematic revision cannot be attempted here (nor do we believe that revision will be worthwhile until substantial new discoveries are made). In its stead, we provide a brief review of fossil occurrences, as a basis for discussion of diversity patterns through time. The review is arranged by geologic age; lacking a repeatable systematic framework, species are listed alphabetically within each epoch (Table 2). One occurrence is noted in this introductory paragraph because age and provenance are uncertain. This is UNSM 50993, a gigantic (maximum dimension $=117 \mathrm{~mm}$ ) pterygopalatine plate described by Shimada and Kirkland (2011). The specimen, which undoubtedly represents a distinct, unnamed species of flat-crowned ceratodontid, was found in the outcrop belt of Miocene- to Pliocene-age deposits of the Ogallala Formation in western Nebraska, and was probably transported from a Jurassic or Cretaceous unit to the west.

Early Jurassic.- - North America's earliest ceratodontids are of Early Jurassic age; two taxa are currently known, one not positively identified. Ceratodus stewarti Milner and Kirkland, 2006 was originally recognized on the basis of a single prearticular plate (UMNH 16027) from the Whitmore Point Member of the Moenave Formation, Utah. The only known pterygopalatine plate, described herein, hails from the stratigraphically higher Kayenta Formation, also in Utah. The species generally resembles Potamoceratodus guentheri (below), although it appears to be more closely related to Early Cretaceous $C$. kirklandi n. sp. The known range of $C$. stewarti is Hettangian-Sinemurian.

The other Early Jurassic occurrence is an unidentified taxon, Potamoceratodus cf. P. guentheri, based on MCZ 13865, a prearticular plate distinguished from the otherwise similar Ceratodus stewarti in having higher crests and more acute angulation of $\mathrm{C}_{1} \mathrm{C}_{\mathrm{p}}$ (Milner and Kirkland, 2006), as well as 
lacking the twinned $\mathrm{C}_{\mathrm{p}}$ crest on the lower plates. The specimen is from the Kayenta Formation of northern Arizona.

Late Jurassic.-No ceratodontids are yet recorded from the Middle Jurassic, but the Morrison Formation (KimmeridgianTithonian) has yielded four species. Ceratodus americanus Knight, 1898 is represented by UWM 2001b, a right pterygopalatine plate lacking $C_{1}$. Kirkland (1987) considered C. americanus a junior subjective synonym of Potamoceratodus guentheri (Marsh, 1878), based on specimens incorrectly referred to the latter species. Correcting this error, he later (Kirkland, 1998) transferred those specimens to a new species, Ceratodus fossanovum Kirkland, 1998 (misspelling in the original; intended naming for Como Quarry 9 would be fossanovem). Given the earlier referral of UWM 2001b, it is logical to wonder whether C. americanus might be a senior subjective synonym of C. fossanovum, which it closely resembles. Considering the incompleteness of UWM 2001b, we defer this taxonomic pitfall, and provisionally regard $C$. americanus as a nomen dubium (see Mones, 1989) for present purposes.

Ceratodus fossanovum is the best-represented (in terms of number of specimens) and most stratigraphically restricted of Ceratodontidae from the Morrison Formation: it is unequivocally known only from Quarry 9 (see Simpson, 1926; Carrano and Velez-Juarbe, 2006) and nearby, stratigraphically equivalent sites in the Como Bluff area, Wyoming. Available fossils show size variation, perhaps related to ontogenetic age. Ceratodus fossanovum resembles $P$. guentheri, differing in its larger size, more obtuse inner angle (ABC), and presence of a crushing platform on tooth plates. In these respects, it is morphologically closest to Early Cretaceous $C$. nirumbee $\mathrm{n}$. sp.

The record of Ceratodus frazieri Ostrom, 1970 in the Morrison Formation is based on a lower tooth plate and nearly complete prearticular (SDSM 426) described by Pinsof (1983). As noted by Kirkland (1987), it is strikingly similar to specimens from the Cloverly Formation (Albian, Early Cretaceous; see Fig. 2.12, 2.13, and Supplemental Data 8), including the holotype, YPM 5276. OMNH 04033, a pterygopalatine plate from the upper Morrison Formation of western Oklahoma, was also provisionally identified as $C$. frazieri (see Kirkland, 1998, fig. 3G). The specimen is broadly similar to KUVP 16226, an upper tooth plate from the Kiowa Shale (Lower Cretaceous) of Kansas, referred to C. frazieri by Schultze (1981). Both are rather flat, with a slightly excavated (concave) occlusal surface, and have relatively wide notches between the ridges. OMNH 04033 is somewhat smaller and is labiolingually narrower, with a more tapering, less quadrate posterior margin, and with a somewhat thicker crown and distinct labial ridge crests. Whether these differences are ontogenetic or taxonomic cannot be determined with material in hand; we accept Kirkland's (1998) referral for purpose of this review.

Potamoceratodus guentheri (Marsh, 1878) (same as, or including Ceratodus felchi Kirkland, 1987) was the first dipnoan to be named from the Morrison Formation. It is a high-crested form with slightly acute $\mathrm{C}_{1} \mathrm{C}_{\mathrm{p}}$ angle, and is among the smallest of North America's post-Triassic lungfish; it is also notable in being the only North American ceratodontid known by cranial material (Pardo et al., 2010). A reasonable sample of tooth plates is known from Felch Quarry in the lower part of the Morrison Formation (Kirkland, 1987). Potamoceratodus guentheri is also known from geographically and stratigraphically scattered sites in the unit (Kirkland, 1998), and it, or a closely similar species, is represented in the Early Jurassic of Arizona. Two species with morphologically similar tooth plates are also known from the Cretaceous of Texas (Main et al., 2014; Parris et al., 2014).

Ceratodus robustus Knight, 1898 is represented by a small sample that nonetheless includes all upper (pterygopalatine, vomerine) and lower (prearticular) tooth plates, as well as specimens exhibiting a range of variation (Kirkland, 1987, 1998). Ceratodus robustus is known from several sites, all in the Morrison Formation of Wyoming. Until now, it has been regarded as unique among North American species of Ceratodus, and has been occasionally cited in connection with possible relatives from other landmasses (e.g., Kirkland, 1987, 1998; Kemp, 1993; Pardo et al., 2010). Ceratodus molossus n. sp. is closely similar, and suggests that the clade survived into the Late Cretaceous.

Early Cretaceous.-We recognize six species of Ceratodus from geographically and stratigraphically scattered sites in the Early Cretaceous of North America. Of these, C. kirklandi n. sp., C. kempae n. sp. (both from the Valanginian of Utah), and C. nirumbee n. sp. (Albian, Montana) are described herein and need no further comment. Ceratodus frazieri Ostrom, 1970, the first ceratodontid to be named from the Early Cretaceous of North America, was recognized on the basis of a left prearticular plate, YPM 5276 (Ostrom, 1970, plate 9A), from unit V of the Cloverly Formation, Wyoming. Kirkland (1987, plate 1F) illustrated another prearticular plate (MOR 367). Oreska et al. (2013) referred several incomplete tooth plates to $C$. frazieri. The most complete and the only of these to be illustrated, USNM 546680 (Oreska et al., 2013, fig. 5A), is consistent with C. frazieri in being low crowned with rather robust, short ridges, though it is not sufficiently complete for secure identification. Interestingly, it is small (maximum preserved length $=26 \mathrm{~mm}$ ), and may represent an immature individual. An additional specimen (OMNH 60408; Fig. 2.12, 2.13, and Supplemental Data 8) from the Cloverly Formation at OMNH locality V1075 in Big Horn County, Montana, resembles the holotype and can unambiguously be referred to C. frazieri. Schultze (1981) referred to C. frazieri a large, flat-crowned pterygopalatine plate (KUVP 16262) from the Kiowa Formation (Albian) of western Kansas. The age and morphology of the specimen are appropriate for the species, and we follow Kirkland $(1987,1998)$ in accepting this referral. Kirkland (1987) also suggested possible referral of UCM 49389 (large tooth plate fragments) to this species. The fossils are said to come from the lower part of the Cedar Mountain Formation, central Utah. This unit includes several members, collectively spanning much of the Early Cretaceous and extending to (or just past) the Early-Late Cretaceous boundary (e.g., Kirkland et al., 1997, 1999). We have not studied the material, and given that the specimens are incomplete and were not illustrated, they can be ignored for present purposes.

Ceratodus kranzi Frederickson, Lipka, and Cifelli, 2016 is based on an incomplete pterygopalatine plate, USNM 508543, from the Arundel Clay facies (Aptian-Albian) of the Potomac Formation, Maryland. This specimen represents a 
large, robust-plated ceratodontid, most similar in appearance to KUVP 16262 (see Schultze, 1981) from the Kiowa Shale. USNM 508543 is one of only two described Cretaceous dipnoan fossils from eastern North America, and the only one from the Early Cretaceous.

Thurmond (1974) reported a sharp-crested species of Ceratodus in the Butler Farm local fauna, Paluxy Formation, Texas. He compared then-available specimens favorably to C. americanus (herein regarded as a nomen dubium) from the Morrison Formation. Kirkland (1987) regarded the Trinity species as an unnamed relative of what he later (Kirkland, 1998) described as C. fossanovum, also from the Morrison Formation. The Trinity species was formally described as Ceratodus texanus Parris, Grandstaff, and Banks, 2014, based on eight specimens (four pterygopalatine and four prearticular tooth plates) from localities in the Twin Mountains and Paluxy formations (Aptian-Albian, see Winkler et al., 1990), northcentral Texas. Parris et al. (2014) compared C. texanus favorably with both Potamoceratodus guentheri and C. fossanovum, distinguishing the species on the basis of size and differences in angles formed by major crests.

Late Cretaceous.-Non-marine vertebrates of North America's Late Cretaceous are incomparably better sampled than those of the Early Cretaceous (e.g., Kielan-Jaworowska et al., 2004; Weishampel et al., 2004; Benson et al., 2013). In this context, the fact that only four ceratodontids are known for the Late Cretaceous suggests a real decline in diversity of the group. (Two additional taxa from the Late Cretaceous, Ceratodus cruciferus Cope, 1876 and C. hieroglyphus Cope, 1876, were transferred to Acipenser by Estes [1964]). Three of the four are of Cenomanian (early Late Cretaceous) age. Ceratodus molossus n. sp., a large species with flat-crowned tooth plates (described herein), is from the Cedar Mountain and Naturita formations of Utah and is a probable relative of Late Jurassic C. robustus. Ceratodus gustasoni Kirkland, 1987, somewhat smaller but also flat-crowned, also comes from the Cenomanian of Utah. The holotype, UCM 54074, and paratype, UCM 54073, are both left prearticular plates. Although other specimens have since been discovered (Fig. 2.14, 2.15, and Supplemental Data 9), pterygopalatine plates for this species are still unknown. Fossils of juveniles have been referred to the species (Brinkman et al., 2013, fig. 10.30), but these are uninformative. Kirkland (1987) hypothesized that $C$. gustasoni may be closely related to C. frazieri, differing most noticeably from this species by its posteriorly expanded lingual margin. A specimen of a juvenile, identified as Ceratodus sp. indet. and recently described from a Santonian level in the Iron Springs Formation, may belong to C. gustasoni (Eaton et al., 2014). Regardless, the specimen is of interest because it and an undescribed species from Los Peyotes, Coahuila Mexico (Coniacian-Santonian) (González-Rodríguez et al., 2016) represent the geologically youngest published ceratodontids from the Western Interior. However, putative lungfish remains have also been discovered from the lower Campanian part of the Aguja Formation of Western Texas (Wick et al., 2015; personal communication, A.A. Brink, 2016). If confirmed through future study and publication, this material would significantly extend the known range of lungfish from Laramidia (the western part of North America, separated from
Appalachia by the Western Interior during much of the Late Cretaceous; Archibald, 1996).

Ceratodus carteri Main, Parris, Grandstaff, and Carter, 2014 is represented by a relatively large sample, with seven known tooth pates (one pterygopalatine and the remainder prearticulars) from the Woodbine Formation (Cenomanian) of Tarrant County, Texas. The sample also includes a wide size range, presumably reflecting different ontogenetic ages. In general, this species is most similar to the tall-crested $P$. guentheri. Ceratodus carteri also resembles tall-crested C. texanus (as noted by Parris et al., 2014), C. nirumbee (both Early Cretaceous), and $C$. fossanovum (Late Jurassic), but differs in its smaller size, more obtuse $\mathrm{C}_{1} \mathrm{C}_{\mathrm{p}}$ angle, and lack of a crushing platform.

A right prearticular and overlying plate (NJSM 18774), found at the Big Brook locality in Monmouth County, New Jersey, represents the geologically youngest occurrence of Ceratodontidae in North America, and is one of only two specimens from the eastern seaboard of the continent. Specimens from the Big Brook locality probably come from the Mount Laurel Formation and are of Campanian age (Gallagher et al., 1986; Lauginiger, 1986). NJSM 18774 is structurally indistinguishable from prearticular plates of Ceratodus frazieri from the Cloverly Formation. Parris et al. (2004) identified the Big Brook specimen as Ceratodus sp. aff. $C$. frazieri, commenting that it probably represents a different species owing to its occurrence. We do not disagree, but because there is no anatomical basis for this distinction, we simply refer the specimen to $C$. frazieri without issue. Just as Ceratodus is regarded as a form genus among Ceratodontidae (e.g., Schultze, 1981), so might $C$. frazieri well be taken as a form species within that genus.

Diversity and paleoecology.-As noted, the nature of the fossil record of post-Triassic lungfishes in North America-which consists almost entirely of rather simple tooth plates-places serious constraints on phylogenetic and paleobiologic inference. In this case, the path of reasoned commentary lies perilously close to a chasm of fantasy. These caveats notwithstanding, we find ourselves largely in agreement with phylogenetic and ecomorphologic interpretations proposed by previous authors (Kirkland, 1987, 1998; Parris et al., 2014), although we are unconvinced that existing data support recognition of ancestor-descendant relationships. The welcome new additions to the fossil record help span temporal and geographic gaps, and add considerably to diversity of North American Mesozoic ceratodontids. We propose a simple model, consisting of four species groups, to serve as a framework for discussing the post-Triassic evolutionary history of dipnoans in North America.

As noted by Kirkland (1987), tooth plates of North American ceratodontids span a morphological continuum, from small, high-crested Potamoceratodus guentheri to large, flat-crowned Ceratodus robustus. Our four species groups are named for the four species from the Upper Jurassic Morrison Formation: P. guentheri, C. fossanovum, C. frazieri, and $C$. robustus. The categories are phenetic: we do not intend these groups as definable phylogenetic units, although in most cases a close relationship of within-group species represents a 


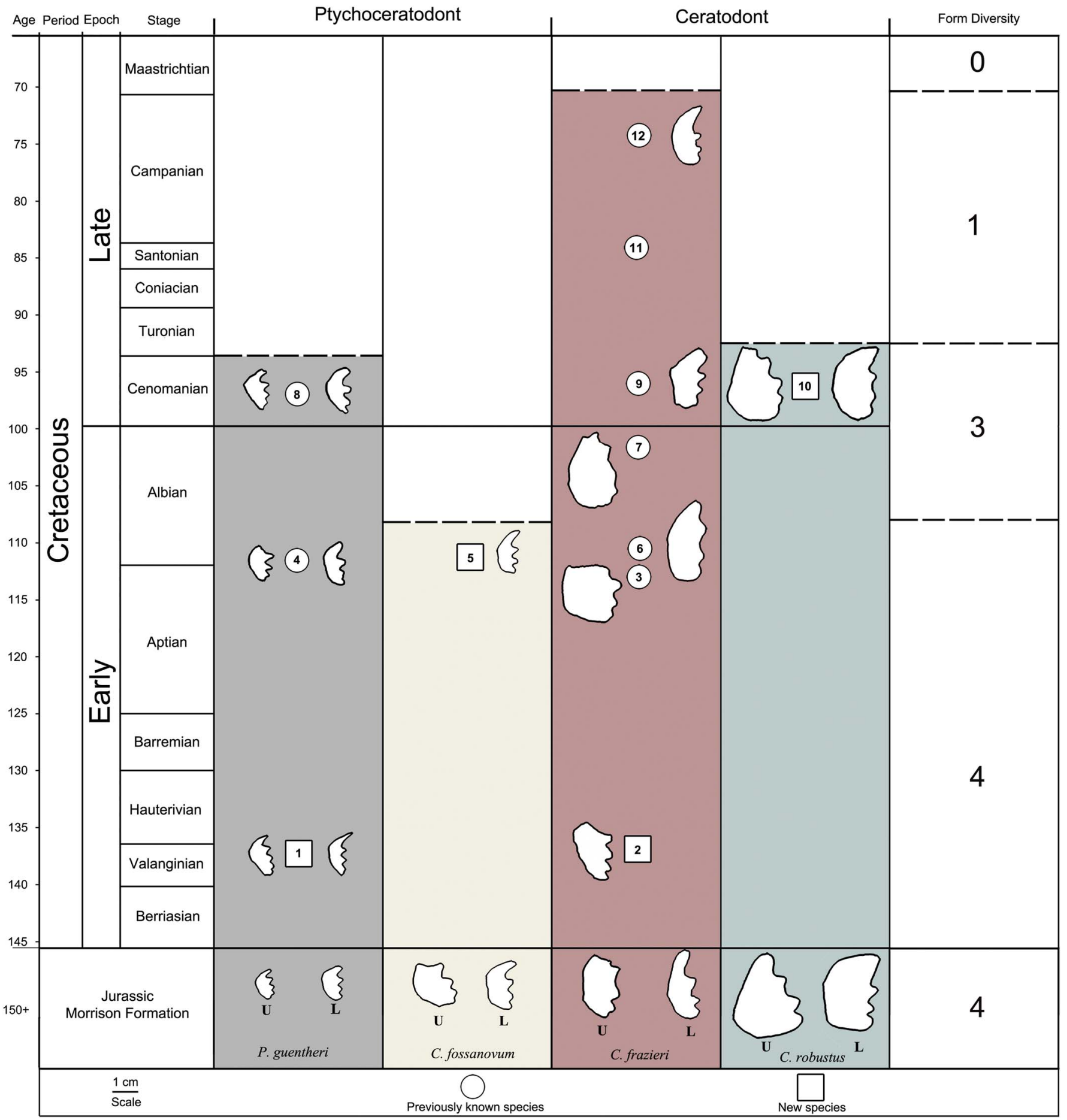

Figure 4. Ceratodus diversity through the Cretaceous of North America, based on the four Jurassic forms (bottom). Major morphotypes ('Ptychoceratodont' and 'Ceratodont,' top) after Parris et al. (2014). Colored columns represent species groups discussed in the text (also indicated by name at base of each column); the form diversity column, right, represents total number of species groups present in given interval (epoch, denoted by dashed horizontal lines). (1) C. kirklandi n. sp.; (2) C. kempae n. sp.; (3) C. kranzi; (4) C. texanus; (5) C. nirumbee n. sp.; (6) C. frazieri; (7) C. frazieri; (8) C. carteri; (9) C. gustasoni; (10) C. molossus n. sp.; (11) C. gustasoni (no images of diagnostic fossil available); (12) C. frazieri. Silhouettes modified from images in Kirkland (1987), Parris et al. (2004, 2014), Main et al. (2014), and Frederickson et al. (2016). Time scale from Cohen et al. (2013). Specimens from the Willow Tank Formation, Nevada; Los Peyotes, Mexico; and the Aguja Formation, Texas are mentioned in the discussion, but not shown in this figure.

plausible working hypothesis. Broadly speaking, at least, it is also reasonable to suppose that these groups reflect ecomorphological differences among species. Small-bodied taxa with high-crested tooth plates, suggestive of some cutting/slicing ability, are presumed to have relied on soft dietary fare, perhaps including invertebrates; whereas larger ceratodontids having heavily built, flat tooth plates may have had a more varied menu, including shelled prey (Kirkland, 1987; Bakker, 2009).

Following our grouping scheme, the earliest post-Triassic dipnoans in North America are both members of the 

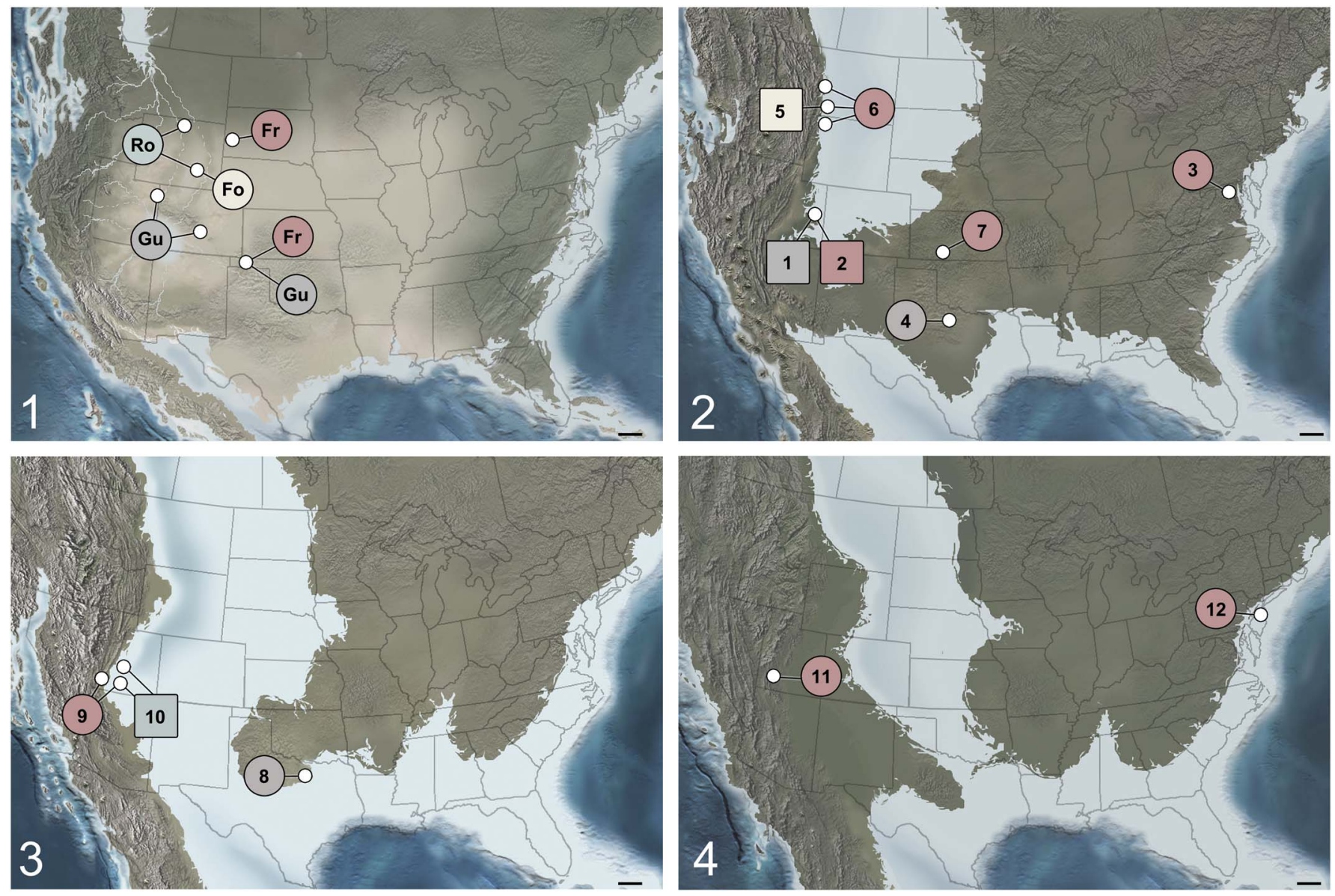

Figure 5. Maps showing approximate North American lungfish distribution during the: (1) Kimmeridgian to Tithonian, Late Jurassic (Kirkland, 1987, 1998; Pardo et al., 2010); (2) Valanginian to Albian, Early Cretaceous (Ostrom, 1970; Schultze, 1981; Kirkland, 1987; Oreska et al., 2013; Parris et al., 2014; Frederickson et al., 2016); (3) Cenomanian, Late Cretaceous (Kirkland, 1987; Main et al., 2014); (4) Santonian to Campanian, Late Cretaceous (Parris et al., 2004). Numbers and color grouping correspond to Figure 4; abbreviations for species groups (1): Fr, Ceratodus frazieri; Fo, C. fossanovum; Gu, Potamoceratodus guentheri; and Ro, C. robustus. Maps modified from ( ) Ron Blakey, Colorado Plateau Geosystems, and were chosen based on their best fit to the depositional environments observed at all of the fossil sites, combined with the closest temporal representation available. Specimens from the Willow Tank Formation, Nevada; Los Peyotes, Mexico; and the Aguja Formation, Texas are mentioned in the discussion but not shown in this figure. Scale bar $=200 \mathrm{~km}$.

P. guentheri group (C. stewarti and Potamoceratodus cf. P. guentheri; Milner and Kirkland, 2006; this study) from the Early Jurassic of the southwest (Moenave and Kayenta formations). Intriguingly, tooth plates of $C$. stewarti bear a twinned $\mathrm{C}_{\mathrm{p}}$ ridge, a feature also seen in Early Cretaceous C. kirklandi (Valanginian, Utah), suggesting the possibility of a sub-clade within the $P$. guentheri group - which itself may or may not be monophyletic. By the Late Jurassic, diversity vastly increases, with all four groups co-occurring in the Morrison Formation. Given the current gap in knowledge for terrestrial ecosystems of the Middle Jurassic of North America (not to mention poor anatomical representation of fossil lungfishes generally), it is currently unknown whether any of these novel groups are derived from the P. guentheri group (Parris et al., 2014) or immigrants from other continents. Significantly, all of this additional diversity involves taxa characterized by larger size and increased crushing capacity. Most distinctive in this regard is $C$. robustus, which has been compared favorably with C. kaupi Agassiz, 1838 (Triassic, Europe) and C. diutinus Kemp, 1993, which ranges from the Aptian-Miocene of Australia (Kemp, 1993). Assuming non-convergent withingroup relationships, all four species groups present in the
Morrison Formation survived into the Albian, after which the C. fossanovum group disappears, followed by the $P$. guentheri group and the C. robustus group after the Cenomanian (Fig. 4). Unquestionably the most noteworthy recent improvement in the record of North American ceratodontids is in the medial Cretaceous (Albian-Cenomanian), with the addition of four species, collectively representing three of the four groups (Main et al., 2014; Parris et al., 2014; this study). Among these, the most surprising is the Cenomanian C. molossus n. sp., which appears to be a close relative of $C$. robustus, and hence represents the only record of the $C$. robustus group outside of the Morrison Formation of Wyoming.

The existing record, including these new occurrences, suggests that lungfish diversity in North America remained relatively stable from the Late Jurassic through the Cenomanian - an interval of $\sim 60 \mathrm{Ma}$ (time scale after Cohen et al., 2013) (Fig. 4). To date, geologically younger horizons have yielded only two described specimens: one from the probable Santonian of Utah (Eaton et al., 2014) and the other from the Campanian of New Jersey (Parris et al., 2004). Both belong to the $C$. frazieri group; the last-surviving member presumably occurred in a refugium on the east coast of Appalachia, which was then separated from Laramidia (and its 
well-known Late Cretaceous vertebrate faunas) by the Western Interior Seaway. Given the general scarcity of dipnoan fossils and inadequate knowledge of early Late Cretaceous assemblages, little more can be said about the decline and extinction of lungfishes in North America. It is worthwhile noting, however, that the major drop in abundance and diversity occurs within the context of a broader turnover event among aquatic taxa at the CenomanianTuronian boundary (Eaton et al., 1997; Brinkman et al., 2013).

North American Ceratodus species are known from a variety of aquatic environments. Most commonly found in freshwater lake or stream deposits (Kirkland, 1987), it is likely that many of these species had lifestyles similar to the modern Australian lungfish (Neoceratodus forsteri), inhabiting diverse freshwater waterways, but preferring straight, flowing streams and rivers bordered by heavy vegetation and containing woody debris (Kemp, 1986; Arthington, 2009). Although often found in a range of low-quality habitats, members of this species are largely salt intolerant, incapable of living in or migrating through saline waters (Arthington, 2008). Similar to the modern Neoceratodus, Jurassic North American ceratodontids appear to be limited to terrestrial environments. The Early Jurassic species ( $P$. guentheri group) are only known from freshwater deposits in the Moenave and Kayenta formations. The holotype of C. stewarti, for example, was discovered as part of a relatively diverse lacustrine fauna (Milner and Kirkland, 2006). Similarly, Late Jurassic species are found in terrigenous rocks deposited under generally arid conditions (Engelmann et al., 2004), with most fossils deriving from fluvial (Kirkland, 1987) or lacustrine (Pardo et al., 2010) facies, far from marine habitats (Fig. 5.1).

By contrast, Early Cretaceous occurrences (Fig. 5.2) of North American Ceratodontidae occur in a wider range of depositional settings, varying from fluvial (Ostrom, 1970) to nearshore marine (Schultze, 1981). Species from the Late Cretaceous (Fig. 5.3, 5.4) all occur in close proximity to the paleo-shoreline, and several sites lie in horizons that were probably deposited under brackish or marine settings. Within the $C$. frazieri group, for example, at least two specimens derived from nearshore marine deposits (Schultze, 1981; Parris et al., 2004), and one is from a possibly paludal setting (Frederickson et al., 2016). Other large ceratodontids may have also had some degree of salt tolerance. For example, fossils of C. molossus (C. robustus group) and C. gustasoni (C. frazieri group) were found in the near-coastal sediments of the Naturita Formation (Kirkland, 1987; this study). Similarly, a Late Cretaceous member of the $P$. guentheri group $(C$. carteri) is known from a deltaic plain or coastal wetland environment (Main et al., 2014), suggesting that salt tolerance may have developed among gracile species groups as well. Notably, the $P$. guentheri and $C$. frazieri groups are also the only dipnoans known from Appalachia during the Cretaceous, although it is likely that they inhabited the area prior to completion of the Western Interior Seaway. At least one Australian species of Ceratodus, wide-ranging C. diutinus, occurs in both freshwater and marine units (Kemp, 1993). Ceratodus also occurs in the marine Westbury Formation (Late Triassic) of Britain, but the vertebrate fossils from this unit apparently represent a mixed assemblage (Storrs, 1993), so the origin of the lungfish specimens is unclear.
Alternatively, it could be argued that all of these later brackish to saltwater occurrences represent reworked material from freshwater settings. Indeed, the Campanian C. frazieri fossil from New Jersey was said to be "taphonomically mature" (Parris et al., 2004, p. 65), indicating that this specimen was transported prior to final burial. In most cases, however, reworking hypotheses are based on behavioral observations of salt intolerant modern lungfish and not paleontological evidence (Kirkland, 1987; Kemp, 1993). In isolated cases, the reworking hypothesis may seem more parsimonious, but taken as a whole, the Ceratodus record of the Late Cretaceous of North America appears to include more coastal, or at least coastal adjacent, settings, than that of the preceding Jurassic.

Besides a functional lung, Dipnoi possess a variety of traits that allow them to survive in an array of environments, including ephemeral bodies of water. For example, aestivation allows living lepidosirenids (Lepidosiren and Protopterus) to lie dormant in an underground cocoon of mucus during drought. Trace fossils interpreted as aestivation chambers belonging to the basal dipnoan Gnathorhiza can be locally quite common in Paleozoic rocks of North America (e.g., Carlson, 1968; Berman, 1976), implying that this behavior has a deep history within the evolution of the clade. The most basal living species of lungfish (Neoceratodus forsteri), however, does not aestivate. By analogy, and noting the absence of identified aestivation burrows in geologically younger rocks, Kirkland (1987; see also Bakker and Bir, 2004) suggested that post-Triassic North American lungfish did not aestivate either. Conversely, in their phylogeny of Dipnoi, Cavin et al. (2007) hypothesized that all taxa more derived than Neoceratodus (including Ceratodus) would have been exclusively freshwater fish that were capable of aestivating during dry spells. Burrows of the correct size and shape to accommodate a full-grown Ceratodus would hypothetically be conspicuous, especially for some of the larger species, but to date none has been found. Thus we tentatively reject the hypothesis of Cavin et al. (2007) because: (1) North American ceratodontids may not have been limited to freshwater habitats, and (2) there is no evidence for dipnoan aestivation chambers in the Jurassic and Cretaceous of North America. The second point also argues against an alternative hypothesis: that marinedwelling Ceratodus may have burrowed during low tide (see Schultze and Chorn, 1997).

\section{Conclusions}

In the three decades since the last systematic treatment of North American ceratodontids (Kirkland, 1987), the number of recognized species has more than doubled, from five to 12 , with most of the new taxa coming from the middle part of the Cretaceous (Albian-Cenomanian). Still, few of these species are known from more than a few specimens, and only one is represented by material other than tooth plates and the bones that bear them. This limitation still makes direct phylogenetic study difficult, and it remains debatable as to whether included species belong to single or multiple genera (see Pardo et al., 2010). Nonetheless, a phenetic approach helps organize species into useful species groups, which, in some cases at least, likely represent clades. Using this technique, it is apparent that all of the Late Jurassic species have at least one morphological 
counterpart in the Early Cretaceous. Similarly, present evidence points to a significant extinction event during the CenomanianTuronian, exterminating all but the $C$. frazieri group. More work is needed to pinpoint the cause of this extinction, as well as to determine the relationships among post-Triassic North American lungfishes. Here, as in so many other cases, the most urgent need is for basic data- a need that can only be addressed by further field work.

\section{Acknowledgments}

For access to specimens in their care, we thank C. Beard, D. Burnham, M. Florence, J. Whitmore Gillette, L. Herzog, J. Krishna, R. Scheetz, V. Schneider, S. Underwood, and L. Zanno. We are grateful to A. Titus and D. Parris for various bits of information, and to R. Burkhalter and J. Cohen for help with photography and 3D digitalization. We also thank B. Grandstaff and L. Cavin for their thoughtful reviews, which greatly benefited this work. Partial support for this research was provided by grants from the National Geographic Society (4761-91, 5021-92, 5918-97, and W266-13) and the National Science Foundation (BSR 8906992, DEB 9401994, 9870173).

\section{Accessibility of supplemental data}

As supplemental data, we provide 3D PDF files for most of the specimens illustrated herein. Data available from the Dryad Digital Repository: https://doi.org/10.5061/dryad.v1jv1

\section{References}

Agassiz, L., 1838, Recherches sur les poissons fossiles. Tome III. Contenant l'Histoire de l'Ordre des Placoïdes: Neuchâtel, Imprimerie de Petitpierre, $7+390+32 \mathrm{p}$.

Archibald, J.D., 1996, Dinosaur Extinction and the End of an Era: What the Fossils Say: New York, Columbia University Press, 237 p.

Arthington, A.H., 2008, Australian lungfish, Neoceratodus forsteri, threatened by a new dam: Environmental Biology of Fishes, v. 84, p. 211-221, doi: 210.1007/s10641-10008-19414-y.

Bakker, R.T., 2009, Turtles at Como: diversity and isolation at the JurassicCretaceous transition: Special Publication of the Royal Tyrrell Museum of Paleontology, Drumheller, Turtle Symposium Abstracts, p. 11-12.

Bakker, R.T., and Bir, G., 2004, Dinosaur crime scene investigations: theropod behavior at Como Bluff, Wyoming and the evolution of birdness, in Currie, P.J., Koppelhus, E.B., Shugar, M.A., and Wright J.L., eds., Feathered Dragons: Bloomington, Indiana University Press, p. 301-342.

Benson, R.B.J., Mannion, P.D., Butler, R.J., Upchurch, P., Goswami, A., and Evans, S.E., 2013, Cretaceous tetrapod fossil record sampling and fauna turnover: implications for biogeography and the rise of modern clades: Palaeogeography, Palaeoclimatology, Palaeoecology, v. 372, p. 88-107.

Berg, L.S., 1940, Classification of fishes, both fossil and recent: Traveaux de l'Institut d'Anthropologie, d'Archéologie et d'Ethnologie: Académie des Sciences de l'URSS, v. 5, p 85-517.

Berman, D.S., 1976, Occurrence of Gnathorhiza (Osteichthyes: Dipnoi) in aestivation burrows in the Lower Permian of New Mexico with description of a new species: Journal of Paleontology, v. 50, p. 1034-1039.

Bonde, J.W., 2008, Paleoecology and taphonomy of the Willow Tank Formation (Albian), southern Nevada [M.S. thesis]: Bozeman, Montana State University, $96 \mathrm{p}$.

Bonde, J.W., Varricchio, D.J., Jackson, F.D., Loope, D.B., and Shirk, A.M., 2008, Dinosaurs and dunes! Sedimentology and paleontology of the Mesozoic in the Valley of Fire State Park, in Duebendorfer, E.M., and Smith, E.I., eds., Field Guide to Plutons, Volcanoes, Faults, Reefs, Dinosaurs, and Possible Glaciation in Selected Areas of Arizona: California, and Nevada, Geological Society of America Field Guide 11, p. 249-262, doi: 10.1130/2008.fld011(11).

Brinkman, D.B., Newbrey, M.G., Neuman, A.G., and Eaton, J.G., 2013, Freshwater Osteichthyes from the Cenomanian to late Campanian of Grand Staircase-Escalante National Monument, in Titus A.L., and Loewen, M.A., eds., At the Top of the Grand Staircase: The Late Cretaceous of Southern Utah: Bloomington, Indiana University Press, p. 195-236.

Carlson, K.J., 1968, The skull morphology and estivation burrows of the Permian lungfish, Gnathorhiza serrata: Journal of Geology, v. 76, p. 641-663.

Carpenter, K., 2014, Where the sea meets the land-the unresolved Dakota problem in Utah: Utah Geological Association Publication, v. 43, p. 357-372.

Carrano, M.T., and Velez-Juarbe, J., 2006, Paleoecology of the Quarry 9 vertebrate assemblage from Como Bluff, Wyoming (Morrison Formation, Late Jurassic): Palaeogeography, Palaeoclimatology, Palaeoecology, v. 237, p. 147-159.

Cavin, L., Suteethorn, V., Buffetaut, E., and Tong, H., 2007, A new Thai Mesozoic lungfish (Sarcopterygii, Dipnoi) with an insight into post-Palaeozoic dipnoan evolution: Zoological Journal of the Linnean Society, v. 149, p. 141-177.

Cifelli, R.L., and Davis, B.M., 2015, Tribosphenic mammals from the Lower Cretaceous Cloverly Formation of Montana and Wyoming: Journal of Vertebrate Paleontology, e920848. doi: 10.1080/02724634.2014.920848:1-18.

Cohen, K.M., Finney, S.C., Gibbard, P.L., and Fan, J.-X., 2013, The ICS international chronostratigraphic chart: Episodes, v. 36, p. 199-204.

Cope, E.D., 1876, Descriptions of some vertebrate remains from the Fort Union beds of Montana: Proceedings of the Academy of Natural Sciences of Philadelphia, v. 1876, p. 248-261.

De Prisco, A., and Johnson, J.B., 1990, The Mini-Atlas of Dog Breeds: Neptune City, New Jersey, TFH Publications, 573 p.

Eaton, J.G., Kirkland, J.I., Hutchison, J.H., Denton, R., O'Neill, R.C., and Parrish, J.M., 1997, Nonmarine extinction across the Cenomanian-Turonian (C-T) boundary, southwestern Utah, with a comparison to the CretaceousTertiary (K-T) extinction event: Geological Society of America Bulletin, v. 109 , p. $560-567$

Eaton, J.G., Gardner, J.D., Kirkland, J.I., Brinkman, D.B., and Nydam, R.L., 2014 Vertebrates of the Iron Springs Formation, Upper Cretaceous, southwestern Utah: Utah Geological Association Guidebook, v. 43, p. 523-555.

Engelmann, G.F., Chure, D.J., and Fiorillo, A.R., 2004, The implications of a dry climate for the paleoecology of the fauna of the Late Jurassic Morrison Formation: Sedimentary Geology, v. 167, p. 297-308.

Estes, R., 1964, Fossil vertebrates from the Late Cretaceous Lance Formation, eastern Wyoming: University of California Publications in Geological Sciences, v. 49, 169 p.

Frederickson, J.A., Lipka, T.R., and Cifelli, R.L., 2016, A new species of the lungfish Ceratodus (Dipnoi) from the Early Cretaceous of the eastern U.S.A Journal of Vertebrate Paleontology, doi: 10.1080/02724634.2016.1136316.

Gallagher, W.B., Parris, D.C., and Spamer, E.E., 1986, Paleontology, biostratigraphy, and depositional environments of the Cretaceous-Tertiary transition in the New Jersey Coastal Plain: The Mosasaur, v. 3, p 1-35.

Gill, T.N., 1872, Arrangement of the families of fishes, or classes Pisces, Marsipobranchii and Leptocardii: Smithsonian Miscellaneous Collections, v. 11, n. 247,49 p.

González-Rodríguez, K.A., Fielitz, C., Bravo-Cuevas, V.M., and Baños-Rodríguez, R.E., 2016, Cretaceous osteichthyan fish assemblages from Mexico: New Mexico Museum of Natural History and Science Bulletin, v. 71, p. 1-14.

Hendrix, B., Moeller, A., Ludvigson, G., Joeckel, R.M., and Kirkland, J.I., 2015 A new approach to date paleosols in terrestrial strata: a case study using $\mathrm{U}-\mathrm{Pb}$ zircon ages for the Yellow Cat Member of the Cedar Mountain Formation of eastern Utah: Geological Society of America, Abstracts with Programs, v. 47, p. 597.

Kauffman, E.G., and Caldwell, W.G.E., 1993, The Western Interior Basin in space and time, in Caldwell, W.G.E., and Kauffman, E.G., eds., Evolution of the Western Interior Basin: Geological Association of Canada Special Paper, v. 39, p. 1-30.

Kemp, A., 1986, The biology of the Australian lungfish, Neoceratodus forsteri: Journal of Morphology, Centennial Supplement, v. 1, p. 181-198.

Kemp, A., 1993, Ceratodus diutinus, a new ceratodont from Cretaceous and late Oligocene-medial Miocene deposits in Australia: Journal of Paleontology, v. 67 , p. $883-888$.

Kemp, A., 1997, A revision of Australian Mesozoic and Cenozoic lungfish of the family Neoceratodontidae (Osteichthyes: Dipnoi), with a description of four new species: Journal of Paleontology, v. 71, p 713-733.

Kemp, A., 2001, Consequences of traumatic injury in fossil and Recent dipnoan dentitions: Journal of Vertebrate Paleontology, v. 21, p. 13-23.

Kemp, A., 2003, Dental and skeletal pathologies in lungfish jaws and tooth plates: Alcheringa, v. 27, p. 155-170.

Kemp, A., and Molnar, R.E., 1981, Neoceratodus forsteri from the Lower Cretaceous of New South Wales, Australia: Journal of Paleontology, v. 55, p. 211-217.

Kielan-Jaworowska, Z., Cifelli, R.L., and Luo, Z.-X., 2004, Mammals from the Age of Dinosaurs: Origins, Evolution and Structure: New York, Columbia University Press, 630 p.

Kirkland, J.I., 1987, Upper Jurassic and Cretaceous lungfish tooth plates from the Western Interior, the last dipnoan faunas of North America: Hunteria, v. 2 , p. $1-16$. 
Kirkland, J.I., 1998, Morrison fishes: Modern Geology, v. 22, p. 503-533.

Kirkland, J.I., Britt, B., Burge, D.L., Carpenter, K., Cifelli, R.L., Decourten, F.L., Eaton, J.G., Hasiotis, S., and Lawton, T., 1997, Lower to middle Cretaceous dinosaur faunas of the central Colorado Plateau: a key to understanding 35 million years of tectonics, sedimentology, evolution and biogeography: Brigham Young University Geology Studies, v. 42, p. 69-103.

Kirkland, J.I., Cifelli, R.L., Britt, B.B., Burge, D.L., Decourten, F.L., Eaton, J.G., and Parrish, J.M., 1999, Distribution of vertebrate faunas in the Cedar Mountain Formation, east-central Utah, in Gillette, D.D., ed., Vertebrate Paleontology in Utah: Salt Lake City, Utah Geological Survey, Miscellaneous Publication 99-1, p. 201-218.

Knight, W.C., 1898, Some new Jurassic vertebrates from Wyoming: American Journal of Science, ser. 4, v. 5, p. 186.

Lauginiger, E.M., 1986, An Upper Cretaceous vertebrate assemblage from Big Brook: New Jersey, The Mosasaur, v. 3, p. 53-61.

Linderman, F.B., 1957, Plenty-coups: Chief of the Crows: Lincoln, University of Nebraska Press, 204 p.

Long, J.A., 2010, The Rise of Fishes: 500 Million Years of Evolution, second edition., Baltimore, Johns Hopkins University Press, 287 p.

Lucas, S.G., Heckert, A.B., and Tanner, L.H., 2005, Arizona's Jurassic fossil vertebrates and the age of the Glen Canyon Group: New Mexico Museum of Natural History and Science Bulletin, v. 29, p. 95-104.

Main, D.J., 2013, Appalachian delta plain paleoecology of the Cretaceous Woodbine Formation at the Arlington archosaur site: [Ph.D. dissertation] Arlington, University of Texas at Arlington, $585 \mathrm{p}$.

Main, D.J., Parris, D.C., Grandstaff, B.S., and Carter, B., 2014, A new lungfish (Dipnoi: Ceratodontidae) from the Cretaceous Woodbine Formation, Arlington Archosaur Site, north Texas: Texas Journal of Science, v. 63 , p. $283-298$.

Marsh, O.C., 1878, New species of Ceratodus from the Jurassic: American Journal of Science, ser. 3, v. 15, p. 76.

Martin, M., 1982, Nouvelles données sur la phylogénie et la systémique des dipneustes postpaléozoïques, conséquences stratigraphiques et paléogéographiques: Geobios, Mémoire Spécial, v. 6, p. 53-64.

Milner, A.C., and Kirkland, J.I., 2006, Preliminary review of the Early Jurassic (Hettangian) freshwater Lake Dixie fish fauna in the Whitmore Poin Member, Moenave Formation in southwestern Utah: New Mexico Museum of Natural History and Science Bulletin, v. 37, p. 510-521.

Mones, A., 1989, Nomen dubium vs. nomen vanum: Journal of Vertebrate Paleontology, v. 9, p. 232-234.

Müller, J., 1846, Ueber den Bau und die grenzen der Ganoiden und über das System natürliche der Fische: Abhandlungen der Königlichen Akademie der Wissenschaften zu Berlin, Jahre 1844, p. 117-216.

Murray, E., 2008, Ghosts of the Old West: New York, Tom Doherty Associates, $201 \mathrm{p}$.

Oreska, M.P.J., Carrano, M.T., and Dzikiewicz, K.M., 2013, Vertebrate paleontology of the Cloverly Formation (Lower Cretaceous), I: faunal composition, biogeographic relationships, and sampling: Journal of Vertebrate Paleontology, v. 33, p. 264-292.
Ostrom, J.H., 1970, Stratigraphy and paleontology of the Cloverly Formation (Lower Cretaceous) of the Bighorn Basin area, Montana and Wyoming: Peabody Museum of Natural History Bulletin, v. 35, 234 p.

Pardo, J.D., Huttenlocker, A.K., Small, B.J., and Gorman, M.A. II, 2010, The cranial morphology of a new genus of lungfish (Osteichthyes: Dipnoi) from the Upper Jurassic Morrison Formation of North America: Journal of Vertebrate Paleontology, v. 30, p. 1352-1359.

Parris, D.C., Grandstaff, B.S., and Gallagher, W.B., 2004, A lungfish (dipnoan) from the Upper Cretaceous of New Jersey: The Mosasaur, v. 7, p. 65-68.

Parris, D.C., Grandstaff, B.S., and Banks, N.T., 2007, Dental function in lungfishes (Ceratodontidae) from the Cretaceous of north Texas: Journal of Vertebrate Paleontology, v. 27, suppl., p. 127A-128A.

Parris, D.C., Grandstaff, B.S., and Banks, N.T., 2014, Lungfishes from the Trinity Group (Cretaceous) of north Texas: Texas Journal of Science, v. 63 , p. $267-282$.

Pinsof, J.D., 1983, A Jurassic lungfish from western South Dakota: Proceedings of the South Dakota Academy of Sciences, v. 62, p. 75-79.

Schultze, H.-P., 1981, A dipnoan tooth plate from the Lower Cretaceous of Kansas, USA: Transactions of the Kansas Academy of Sciences, v. 84, p. $187-195$.

Schultze, H.-P., and Chorn, J., 1997, The Permo-Carboniferous genus Sagenodus and the beginning of modern lungfish: Contributions to Zoology, v. 67, p. 9-70.

Shimada, K., and Kirkland, J.I., 2011, A mysterious king-sized Mesozoic lungfish from North America: Transactions of the Kansas Academy of Sciences, v. 114, p. 135-141.

Simpson, G.G., 1926, The fauna of Quarry Nine: American Journal of Science, ser. 5 , v. 12 , p. $1-11$.

Storrs, G.W., 1993, Terrestrial components of the Rhaetian (uppermost Triassic) Westbury Formation of southwestern Britain: New Mexico Museum of Natural History and Science Bulletin, v. 3, p 447-451.

Thurmond, J.T., 1974, Lower vertebrate faunas of the Trinity Division in northcentral Texas: Geoscience and Man, v. 8, p. 103-129.

Weishampel, D.B., Dodson, P., and Osmólska, H., 2004, The Dinosauria, second edition., Berkeley, University of California Press, 880 p.

Wick, S.L., Lehman, T.M., and Brink, A.A., 2015, A theropod tooth assemblage from the lower Aguja Formation (early Campanian) of West Texas, and the roles of small theropod and varanoid lizard mesopredators in a tropical predator guild: Palaeogeography, Palaeoclimatology, Palaeoecology, v. 418 , p. $229-244$.

Winkler, D.A., Murry, P.A., and Jacobs, L.L., 1990, Early Cretaceous (Comanchean) vertebrates of central Texas: Journal of Vertebrate Paleontology, v. 10, p. 95-116.

Young, R.G., 1960, Dakota Group of Colorado Plateau: American Association of Petroleum Geologists Bulletin, v. 44, p. 156-194.

Accepted 2 August 2016 